\title{
Aplikasi Asuhan Keperawatan Psikososial Dengan Masalah Kecemasan Pada Penderita Bells Palsy
}

\author{
Nidya Putri
}

Nidyaputri451@gmail.com

\section{BAB I \\ PENDAHULUAN}

\subsection{Latar Belakang}

Bell's palsy merupakan suatu kelumpuhan saraf perifer secara akut pada separuh wajah. Kondisi ini menyebabkan penderita tidak dapat menggerakkan separuh wajah secara volunteer (Mujadidah, 2018) Insiden tahunan terjadinya bell's palsy adalah 20 per 100.000 orang tanpa memandang jenis kelamin maupun etnis. Kejadian tersebut tak memandang usia tetapi cenderung lebih tinggi saat di atas umur 40 tahun. Faktor yang resiko terjadinya bell's palsy ialah diabetes, obesitas, hipertensi, preeklamasi berat dan kehamilan (Patel et al.,2015). Dari seluruh gangguan neuropati pada 4 rumah sakit besar di Indonesia menjelaskan frekuensi penderita bell's palsy sebesar 19,55\% (Mujaddidah, 2018)

Bell's palsy sendiri ialah kelumpuhan wajah sementara pada separuh wajah yang disebabkan oleh traumatic, tekan, infeksi dan inflamasi yang melibatkan saraf diwajah. Hal ini menyebabkan kontrol saraf di wajah seperti berkedip, menutup mata, ekspresi wajah sampai sensasi rasa pengecap di lidah mengalami gangguan (Prabasheela et al., 2017)

Kecemasan merupakan suatu keadaan perasaan gelisah, ketidaktentuan, ada rasa takut dari kenyataan atau persepsi ancaman sumber aktual yang tidak diketahui masalahnya (Pardede \& Simangunsong, 2020). Kecemasan merupakan suatu respon psikologis maupun fisiologis individu terhadap suatu keadaan yang tidak menyenangkan, atau reaksi atas situasi yang dianggap mengancam (Hulu \& Pardede, 2016) 
Di Indonesia prevalensi kecemasan belum diketahui secara pasti, namun diprdiksi sekitar 9-12\% populasi penduduk mengalami kecemasan. Hasil penelitian Apriansyah, Romadoni dan Andrianovita (2014) bahwa responden yang akan dilakukan tindakan operasi mengalami kecemasan kategori sedang dan berat berjumlah 23 responden $(50 \%)$ dari total 46 responden yang diteliti dan kecemasan ringan yang terjadi pada responden demngan keluhan nyeri berjumlah 10 responden $(21,7 \%)$ dari total 46 responden (Pardede, 2021)

Survey awal dilakukan di Amal luhur Helvetia dengan masalah kecemasan atas nama inisial Ny. E, penyebab karena Ny. E belom bisa mengatasi rasa cemas untuk menghadapi penyakit yang dideritanya. Maka tujuan asuhan keperawatan yang akan dilakukan ialah untuk mengajarkan standar pelaksanaan masalah cemas pada Ny. E di Amal Luhur.

\subsection{Rumusan Masalah}

Berdasarkan uraian latar belakang maka penulis membuat rumusan masalah sebagai berikut: Asuhan Keperawatan Pada Ny.E dengan kecemasan di Bakti Luhur.

\subsection{Tujuan}

\subsubsection{Tujuan Umum}

Untuk memberikan asuhan keperawatan pada Ny.E dengan masalah kecemasan

\subsubsection{Tujuan Khusus}

a. Mahasiswa mampu melakukan pengkajian pada Ny.E dengan masalah kecemasan.

b. Mahasiswa mampu menegakkan diagnosa pada Ny.E dengan masalah kecemasan.

c. Mahasiswa mampu membuat intervensi pada Ny.E dengan masalah kecemasan.

d. Mahasiswa mampu melakukan implementasi pada Ny.E dengan masalah kecemasan.

e. Mahasiswa mampu membuat evaluasi pada Ny.E dengan masalah kecemasan.

f. Mahasiswa mampu membuat dokumentasi pada Ny.E dengan masalah kecemasan. 


\section{BAB 2}

\section{TINJAUAN TEORITIS}

\subsection{Konsep Bells Palsy}

\subsubsection{Definisi}

Bell's palsy merupakan suatu sindrom kelemahan wajah dengan tipe lower motor neuron yang disebabkanoleh keterlibatan saraf fasialis perifer yang bersifat unilateraldi luar sistem saraf pusat, idiopatik, akut dan tidak disertaioleh gangguan pendengaran, kelainan neurologi lainnya atau kelainan lokal. Insidensi sindrom ini sekitar 23 kasus per 100000 orang setiap tahun dan meningkat sesuai pertambahan umur. Insiden meningkat pada penderita diabetes dan wanita hamil. Sekitar 8-10\% kasus berhubungan dengan riwayat keluarga pernah menderita penyakit ini.Berbagai teori mencoba menerangkan abnormalitas yang terjadi, salah satunya adalah keterlibatan virus Herpes Simplex tipe 1 Kontroversi dalam tata laksana masih diperdebatkan, walaupun hampir sebagian besar kasus (85\%) sembuh sempurna dalam 1-2 bulan dan rekurensi terjadi pada $8 \%$ kasus.

Dokter di pelayanan primer diharapkan dapat menegakkan diagnosis Bell's palsy serta mengobati dengan tepattanpa melupakan diagnosis banding yang mungkin didapatkan.Sir Charles Bell (1774-1842) dikutip dari Singhi dan Cawthorneadalah orang pertama yang meneliti tentang sindroma kelumpuhan saraf fasialis dan sekaligus meneliti tentang distribusi dan fungsi saraf fasialis. Oleh karena itu nama Bell diambil untuk diagnosis setiap kelumpuhan saraf fasialis perifer yang tidak diketahui penyebabnya.AnatomiSaraf fasialis atau saraf kranialis ketujuh mempunyai komponen motorik yang mempersarafi semua otot ekspresi wajah pada salah satu sisi, komponen sensorik kecil (nervus intermedius Wrisberg) yang menerima sensasi rasa dari 2/3 depan lidah, dan komponen otonom yang merupakan cabang sekretomotor yang mempersarafi glandula lakrimalis.

Saraf fasialis terdiri dari 7 segmen yaitu :

1. Segmen supranuklear

2. Segmen batang otak 
3. Segmen meatal

4. Segmen labirin

5. Segmen timpani

6. Segmen mastoid

\section{Segmen ekstra temporal}

\subsection{Anatomi Fisiologi}

Terdapat lima teori yang kemungkinan menyebabkanterjadinya Bell's palsy, yaitu iskemik vaskular, virus, bakteri, herediter, dan imunologi. Teori virus lebih banyak dibahas sebagai etiologi penyakit ini. Teori iskemik vaskulerTeori ini sangat popular, dan banyak yang menerimanya sebagai penyebab dari bell's palsy. Menurut teori ini terjadi gangguan regulasi sirkulasi darah ke N. VII. Terjadi vasokontriksi arteriole yang melayani N. VII sehingga terjadi iskemik, kemudian diikuti oleh dilatasi kapiler dan permeabilitas kapiler yang meningkat, dengan akibat terjadi transudasi. Cairan transudat yang keluar akan menekandinding kapiler limfe sehingga menutup.

\subsection{Patogenis}

Patogenesis Proses akhir yang dianggap bertanggung jawab atas gejala klinik bell's palsy adalah proses edema yang menyebabkan kompresi N.VII. Pulec memandang BP sebagai suatu sindroma kompresi saraf fasialis atausebagai suatu “entrapment syndrome”.Hingga kini belum ada persesuaian pendapat tentang pathogenesis Bell's palsy, oleh George A. Gates, membagi patogenesis menjadi 3 tipe, yaitu:1.

Tipe 1: Pada tipe 1 mengalami paresis ringan dan sebagian besar mengalami kelumpuhan komplit. Paresis maupun paralisis ini dapat mengalami penyembuhan yang baik, blok konduksi saraf yang reversibel (neuropraksis) adalah akibat dari kompresi yang mendadak oleh karena edema di sekitar saraf dan disebabkan oleh adanya spasmepembuluh darah, namun teori ini belum dapat dibuktikan.Teori lain menjelaskan adanya kerusakan endotel kapiler oleh radang virus yang menyebabkan kebocoran sehingga cairan masukke 
dalam jaringan sekitarnya. Bila cairan ini terkumpul di dalam endoneurium maka konduksi saraf menjadi terhambat.

Tipe 2: Pada tipe ini ditandai dengan timbulnya sinkenesis dan gejala sisa lain yang mungkin akibat degenerasi sarafsinkenesis ini terjadi karena impuls dari satu akson dapat menyebar ke akson yang berdekatan dan berakibat kontraksi otot-otot lain. George A. Gates menjelaskan akan terjadi penjalaran listrik pada waktu terjadi "saltatory movement" kepada saraf yang berdekatan yang mengalami kerusakan myelin sehingga terjadi konduksi pada dua saraf dan kontraksi dua otot pada saat bersamaan.

Tipe 3: Pada tipe ini penyebabnya dimulai dengan degenerasi Wallerian yang terjadi akibat cedera akson dalam segmen labirint dari nervus fasialis, ini terjadi akibat kerusakan yang ditimbulkan oleh virus zooster dalam ganglion genikulatum dan berakibat sensori $2 / 3$ anterior lidah terganggu. Selanjutnya dapat menyebar ke korda timpani, saraf akustik dan vestibuler dan menyebabkan hambatan pengantar akson kemudian terjadi paralisis dan degenerasi.

\subsection{Manifestasi Klinis}

Manifestasi klinis motorik yang dijumpai pada pasien Bell's palsy yaitu adanya kelemahan otot pada satu sisi wajah yang dapat dilihat saat pasien kesulitan melakukan gerakan volunter seperti (saat gerakan aktif maupun pasif) tidak dapat mengangkat alis dan menutup mata, sudut mulut tertarik ke sisi wajah yang sehat (mulut mencong), sulit mencucu atau bersiul, sulit mengembangkan cuping hidung, dan otot-otot yang terkena yaitu m. frontalis, m.orbicularis oculi, m. orbicularis oris, $\mathrm{m}$. zigomaticus dan $\mathrm{m}$. nasalis. Selain tanda-tanda motorik, terjadi gangguan pengecap rasa manis, asam dan asin pada 2/3 lidah bagian anterior, sebagian pasien mengalami mati rasa atau merasakan tebal di area wajahnya. 


\subsection{Pemerikasaan Penunjang}

Bell's palsy merupakan diagnosis klinis sehinggapemeriksaan penunjang perlu dilakukan untuk menyingkirkan etiologi sekunder dari paralisis saraf kranialis. Pemeriksaan radiologis dengan CT-scan atau radiografi polos dapat dilakukan untuk menyingkirkan fraktur, metastasis tulang, dan keterlibatan sistem saraf pusat (SSP). Pemeriksaan MRI dilakukan pada pasien yang dicurigai neoplasma di tulang temporal, otak, glandula parotis, atau untuk mengevaluasi sklerosis multipel. Selain itu, MRI dapat memvisualisasi perjalanan dan penyengatan kontras saraf fasialis.

\subsection{Penatalaksanaan Medis}

Penatalaksanaan Bell's palsy yang penting diketahui oleh dokter umum adalah mengidentifikasi dan merujuk ke dokter spesialis saraf. Dengan kata lain, dokter umum harus mampu menyingkirkan diagnosis lain yang mungkin sebelum menegakkan diagnosis Bell's palsy. Yang pertama kali harus dilakukan setelah penegakan diagnosis adalah segera memulai farmakoterapi dan melindungi mata.

1. Medikamentosa

Karena paralisis otot wajah akan berdampak terhadap penampilan, kualitas hidup, dan psikologis, maka seringkali farmakoterapi diberikan untuk menurunkan resiko terjadinya pemulihan yang tidak sempurna. Farmakoterapi diberikan sesuai dengan penyebabnya.

2. Kortikosteroid

Karena umumnya gejala dipicu oleh edema dan pembengkakan nervus fasialis, maka bisa diberikan antinflamasi kortikosteroid, kecuali bila ada kontraindikasi. Baugh, et al. merekomendasikan bahwa pemberian kortikosteroid sebaiknya diberikan dalam 72 jam setelah onset. Terapi bisa dimulai dengan $60 \mathrm{mg}$ prednisone selama 6 hari kemudian ditappering off $10 \mathrm{mg}$ per hari pada 5 hari berikutnya. Kedua metode ini dilaporkan mempunyai efektivitas yang sama.

Pemberian kortikosteroid harus dilakukan dengan hati-hati pada pasien dengan tuberkulosis, kondisi immunocompromise, kehamilan, infeksi aktif, sarkoidosis, 
sepsis, tukak lambung, diabetes mellitus, disfungsi renal atau hepar, dan hipertensi.

\section{Antiviral}

Bila terdapat kecurigaan penyebab viral, maka antivirus bisa dipertimbangkan. Namun sebaiknya antiviral tidak digunakan sebagai modalitas tunggal tapi dikombinasikan dengan kortikosteroid[2,6]. Antivirus yang bisa diberikan adalah acyclovir $400 \mathrm{mg}$ lima kali sehari selama tujuh hari dan valacyclovir 1 gram tiga kali sehari selama tujuh hari[3]. Kombinasi kortikosteroid dan antiviral direkomendasikan pada dengan yang mengalami gejala berat sampai paralisis sempurna.

\section{Terapi Suportif}

Jika pada pemeriksaan ditemukan adanya gangguan dalam penutupan kelopak mata (muskulus orbicularis oculi), maka perlu diberikan intervensi untuk menjaga kelembaban kornea. Intervensi yang diberikan berupa pemberian air mata buatan pada siang hari dan salep lubrikan pada malam hari untuk mencegah iritasi pada mata. Hal ini karena air mata yang disekresikan oleh kelenjar lakrimal diratakan ke seluruh mata gerakan menutup kelopak mata. Akibatnya pada Bell's palsy terjadi epiphora karena air mata yang disekresikan tidak bisa diratakan ke seluruh mata. Bila mata dibiarkan kering terlalu lama, maka iritasi yang terjadi akan bisa memicu timbulnya keratitis dan ulserasi. Jika terdapat tanda-tanda adanya keratitis atau ulserasi, pasien perlu dirujuk ke spesialis mata.

Pertimbangkan juga untuk melakukan oklusi mata menggunakan plester atau eye patch selama 1-2 hari jika terdapat erosi pada kornea untuk membantu penyembuhannya. Pastikan kelopak mata tertutup sempurna.

Gangguan pada muskulus orbicularis oris juga bisa menimbulkan abrasi sampai ulserasi mukosa akibat proses mastikasi makanan. Jika kelemahan pada muskulus orbicularis oculi signifikan, maka disarankan untuk diet cair atau lunak. Bisa juga diberikan dental spacer untuk mencegah mukosa buccal tergigit ketika mengunyah makanan. 
5. Nonfarmakoterapi

Terapi operatif dengan tujuan untuk dekompresi bisa dilakukan pada kasus dengan pemulihan tidak sempurna, namun tidak direkomendasikan sebagai terapi lini pertama. Terapi nonfarmakologis lain yang bisa diberikan termasuk heat therapy, electrostimulation, denervasi, pijat, mime therapy, dan biofeedback.

6. Manajemen Sekuele

Manajemen untuk penanganan sekuele Bell's palsy telah berkembang dari tehnik untuk suspensi sudut bibir dan penutupan kelopak mata menjadi pendekatan multimodal yang mencakup fisioterapi, chemodenervation, dan prosedur bedah selektif untuk mengoptimalkan fungsi dan kosmetik Sinkinesis bisa ditangani dengan fisioterapi, dengan focus pada latihan-latihan biofeedback untuk melatih kembali simetri fasial dan denervasi selektif dengan injeksi toksin botulinum. Pendekatan lainnya adalah dengan metode operatif untuk mengangkat otot (myomektomi) atau inervasi (neurektomi)

\subsection{Konsep Ansietas}

\subsubsection{Definisi Ansietas}

Ansietas adalah keadaan emosi dan pengalaman subyektif individu, tanpa objek yang spesifik karena ketidaktahuan dan mendahului semua pengalaman yang baru seperti masuk sekolah, pekerjaan baru, atau melahirkan anak (Stuart, 2009). Kecemasan merupakan suatu keadaan perasaan gelisah, ketidaktentuan, ada rasa takut dari kenyataan atau persepsi ancaman sumber aktual yang tidak diketahui masalahnya (Pardede \& Simangunsong, 2020). Kecemasan merupakan suatu respon psikologis maupun fisiologis individu terhadap suatu keadaan yang tidak menyenangkan, atau reaksi atas situasi yang dianggap mengancam (Hulu \& Pardede, 2016)

Ansietas adalah perasan emosional dan tidak nyaman sehingga individu akan meningkatkan kewaspadaan untuk mengantisipasi. Individu yang mengalami ansietas biasanya mereka mereka merasa dirinya tidak bebas, gugup, takut, gelisah, tegang, dan resah. Perasaan yang tidak menentu tersebut pada umumnya tidak menyenangkan yang nantinya akan menimbulkan atau disertai perubahan fisiologis dan psikologis. Ansietas adalah perasaan tidak senang yang khas yang 
disebabkan oleh dugaan akan bahaya atau frustrasi yang mengancam yang akan membahayakan rasa aman, keseimbangan, atau kehidupan seseorang individu atau kelompok biososialnya (Abidin \& hariyanto, 2017)

Kecemasan adalah perasaan tidak nyaman atau khawatir yang samar disertai otonom (sumber seringkali tidak spesifik atau tidak diketahui individu) ; perasaan takut yang disebabkan oleh antisipasi terhadap bahaya. Hal ini merupakan isyarat kewaspadaan yang memperingatkan individu akan adanya bahaya dan memampukan individu untuk bertindak menghadapi ancaman (NANDA, 2018)

\subsubsection{Etiologi}

Meski penyebab ansietas belum sepenuhnya diketahui, namun gangguan keseimbangan neurotransmitter dalam otak dapat menimbulkan ansietas pada diri seseorang. Faktor genetik juga merupakan faktor yang dapat juga menimbulkan gangguan ini, ansietas terjadi ketika seseorang mengalami kesulitan menghadapi situasi, masalah dan tujuan hidup (Videbeck, 2018). Setiap individu menghadapi stress dengan cara berbeda-beda, seseorang dapat tumbuh dalam situasi yang dapa menimbulkan stress berat pada orang lain adapun faktor-faktornya yang mempengaruhi ansietas adalah :

1. Faktor predisposisi

Berbagai teori yang dikembangkan untuk menjelaskan penyebab ansietas adalah:

a. Teori psikionalitik

Ansietas merupakan konflik emosional antara dua elemen yaitu ide, ego dan super ego. Ide melambangkan dorongan insting, ego digambarkan sebagai mediator antara ide dan super ego mencerminkan hati nurani seseorang dan dikendalikan oleh norma-norma budaya seseorang, ansietas berfungsi untuk memperingatkan ego tenang suatu budaya yang perlu segera diatasi (Heather,2019)

b. Teori interpersonal

Ansietas terjadi dari ketakutan akan penolakan interpersonal berhubungan juga dengan trauma masa perkembangan seperti kehilangan, perpisahan. Individu dengan harga diri rendah biasanya sangat mengalami ansietas berat ( Riyadi \& Purwonto, 2017)

c. Teori perilaku 
Ansietas merupakan produk frustasi yaitu segala sesuatu yang yang menggangu kemampuan seseorang untuk mencapai tujuan yang diharapkan (Isaacs, 2019)

d. Kajian biologis

Kajian biologis menunjukan bahwa otak mengandung reseptor khusus untuk benzodiazepin, obat-obatan yang meningkatan neuroregulator yang berperan penting dalam mekanisme biologis yang berhubungan dengan ansietas (Stuart, Keliat \& Pasaribu, 2016)

2. Faktor presipitasi

Bersumber dari eksternal dan internal seperti :

a. Ancaman terhadap integritas fisik meliputi ketidakmampuan fisiologis atau menurunnya kemampuan melaksanakan fungsi kehidpan sehari-hari(Stuart, Keliat \& Pasaribu, 2016)

b. Ancaman terhadap sistem diri dapat membahayakan identitas harga diri dan integritas fungsi sosial. (Stuart, Keliat \& Pasaribu, 2016)

3. Perilaku

Ansietas dapat diekspresikan langsung melalui perubahan fisiologis dan perilaku secara tidak langsung timbulnya gejala atau mekanisme koping dalam meningkat sejalan dengan peningkatan ansietas (Ermawati,2018)

\subsubsection{Tingkat Ansietas}

1. Ansietas Ringan

Ansietas ringan berhubungan dengan ketengan akan peristiwa kehidupan sehari-hari. Pada tingkat ini laangan persepsi melebar dan individu terdorong untuk belajar yang akan menghasilkan pertumbuhan kreatifitas. (Bulechek, 2016)

a. Respon fisiologis

1. Sesekali napas pendek

2. Nadi dan tekanan darah naik

3. Gejala ringan pada lambung

4. Muka berkerut dan bibir bergetar

b. Respon kognitif

1. Lapang persepsi melebar

2. Mampu menerima rangsangan yang kompleks

3. Konsentrasi pada maslah 
4. Menejeaskan masalah secara efektif

c. Respon perilaku dan emosi

1. Tidak dapat duduk tenang

2. Tremor halus pada tangan

3. Suara kadang-kadang meninggi

2. Ansietas sedang

Pada tingkat ini lapangan persepsi terhadap lingkugan menurun. Individu lebih memfokuskan hal-hal penting dan mengenyampingkan hal-hal lain (Bulechek, 2016).

a. Respon fisiologis

1. Nadi (ekstra systole) dan tekanan darah naik

2. Mulut kering

3. Anorexia

4. Diare/konstipasi

5. Gelisah

b. Respon kognitif

1. Lapang persepsi menyempit

2. Rangsang luar tidak mampu diterima

3. Berfokus pada apa yang menjadi perhatian

c. Respon perilaku dan emosi

1. Gerakan tersentak-sentak (meremas tangan)

2. Bicara banyak dan lebih cepat

3. Susah tidur

4. Perasaan tidak aman

3.Ansietas berat

Pada ansietas berat lapangan persepsi menjadi sangat sempit, individu cenderung memikirkan hal yang kecil saja dan mengabaikan hal lain,individu tidak mampu lagi berpikir realistis dan membutuhkan pengarahan untuk memusatkan perhatian pada area lain (Bulechek, 2016).

a. Respon fisiologi

1. Sering nafas pendek

2. Nadi dan tekanan darah naik

3. Berkeringat dan sakit kepala 
4. Penglihatan kabur

5. Ketegangan

b. Respon kognif

1. Lapang persepsi sangat sempit

2. Tidak mampu menyelesaikan masalah

c. Respon perilaku dan emosi

1. perasaan ancam meningkat

2. verbialisasi cepat

3. Blocking

\subsubsection{Mekanisme Koping}

Ketika pasien mengalami ansietas, individu menggunakan bermacammacammekanisme koping untuk mencoba mengatasinya. Dalam bentuk ringan ansietas bentuk ringan ansietas dapat di atasi dengan menangis, tertawa, tidur, olahraga atau merokok. Bila terjadi ansietas berat sampai panik akan terjadi ketidakmampuan mengatasi ansietas secara konstruktif merupakan penyebab utama perilaku yang patologis, individu akan menggunakan energy yang lebih besar untuk dapat mengatasi ancaman tersebut.

Mekanisme koping untuk mengatasi ansietas adalah:

1. Reaksi yang berorientasi pada tugas (task oriented reaction) Merupakan pemecahan masalah secara sadar yang digunakan untuk menanggulangi ancaman stressor yang ada secara realistis yaitu :

a. Perilaku menyerang (Agresif) Biasanya digunakan individu untuk mengatasi rintangan agar memenuhi kebutuhan.

b. Perilaku menarik diri Digunakan untuk menghilangkan sumber ancaman baik secara fisik maupun psikologis.

c. Perilaku kompromi Digunakan untuk merubah tujuan yang akan dilakukan atau mengorbankan kebutuhan personal untuk mencapai tujuan.

2. Mekanisme pertahanan ego (Ego oriented reaction) Mekanisme ini membantu mengatasi ansietas ringan dan sedang yang digunakan untuk melindungi diri dan dilakukan secara sadar untuk mempertahankan keseimbangan. Mekanisme pertahanan ego:

a. Disosiasi adalah pemisahan dari proses mental atau perilaku dari kesadaran atau identitasnya. 
b. Identifikasi (identification) adalah proses dimana seseorang untuk menjadi yang ia kagumi berupaya dengan mengambil/meniru pikiranpikiran, perilaku dan selera orang tersebut.

c. Intelektualisasi (intellectualization) adalah penggunaan logika dan alasan yang berlebihan untuk menghindari pengalaman yang mengganggu perasaannya.

d. Introjeksin (introjection) adalah suatu jenis identifikasi yang dimana seseorang mengambil dan melebur nilai-nilai dan kualitas seseorang atau suatu kelompok kedalam struktur egonya sendiri, berupa hati nurani, contohnya rasa benci atau kecewa terhadap kematian orang yang dicintai, dialihkan dengan cara menyalahkan diri sendiri.

e. Kompensasi adalah proses dimana seseorang memperbaiki penurunan citra diri dengan secara tegas menonjolkan keistimewaan/kelebihan yang dimilikinya. Penyangkalan (Denial) adalah menyatakan ketidaksetujuan terhadap realitas dengan mengingkari realitas tersebut. Mekanisme pertahanan ini adalah penting, sederhana, primitif.

\subsubsection{Tanda dan Gejala Kecemasan}

\section{Respon fisik :}

a. Kardiovaskular : palpitasi, jantung bedebar, tekanan darah meninggi, denyut nadi cepat

b. Pernafasan : napas cepat, napas pendek, tekanan pada dada, napas dangkal, pembengkakan pada tenggorokan, terengah-engah

c. Neuromuskular : refleks meningkat, insomnia, tremor, gelisah, wajah tegang, kelemahan umum, kaki goyah, gerakan yang janggal

d. Gastrointestinal : anoreksia, diare/konstipasi, mual, rasa tidak nyaman pada abdomen

e. Traktur urinarius : sering berkemih dan tidak dapat menahan kencing

f. Kulit : wajah kemerahan, berkeringat, gatal, rasa panas pada kulit

g. Diovaskular : palpitasi, jantung bedebar, tekanan darah meninggi, denyut nadi cepat

h. Pernafasan : napas cepat, napas pendek, tekanan pada dada, napas dangkal, pembengkakan pada tenggorokan, terengah-engah

i. neuromuskular : refleks meningkat, insomnia, tremor, gelisah, wajah tegang, kelemahan umum, kaki goyah, gerakan yang janggal 
j. gastrointestinal : anoreksia, diare/konstipasi, mual, rasa tidak nyaman pada abdomen

k. Traktur urinarius : sering berkemih dan tidak dapat menahan kencing

1. kulit : wajah kemerahan, berkeringat, gatal, rasa panas pada kulit

\section{Respon Kognitif}

Lapang persepsi menyempit, tidak mampu menerima rangsang luar, berfokus pada apa yang menjadi perhatiannya

\section{Respon Prilaku}

Gerakan tersentak-sentak, bicara berlebihan dan cepat, perasaan tidak aman.

\section{Respon Emosi}

Menyesal, iritabel, kesedihan mendalam, takut, gugup, sukacita berlebihan, ketidakberdayaan meningkat secara menetap, ketidakpastian, kekhawatiran meningkat, fokus pada diri sendiri, perasaan tidak adekuat, ketakutan, distressed, prihatin.

\subsubsection{Terapi Keluarga}

\section{Terapi Hipnotis 5 Jari}

Pemberian terapi hipnotis lima jari ialah membantu pasien menurunkan stres tanpa adanya bantuan pharmakologi, memberikan dan meningkatkan pengalaman subjektif bahwa ketegangan fisiologis bisa direlaksasikan sehingga relaksasi akan menjadi kebiasaan berespon pada keadaan-keadaan tertentu ketika otot tegang, menurunkan stres pada individu, mencegah manifestasi psikologis maupun fisiologis yang diakibatkan stress (Marbun, Pardede \& Perkasa, 2019).

\subsection{Konsep Asuhan Keperawatan}

\subsubsection{Pengkajian}

\section{a. Faktor Predisposisi}

Berbagai teori telah dikembangkan untuk menjelaskan asal ansietas:

\section{Teori Psikoanalitik}

Ansietas adalah konflik emosional yang terjadi antara dua elemen kepribadian, ID dan superego. ID mewakili dorongan insting dan impuls 
primitif seseorang, sedangkan superego mencerminkan hati nurani seseorang dan dikendalikan oleh norma- norma budaya seseorang. Ego atau $\mathrm{Aku}$, berfungsi menengahi hambatan dari dua elemen yang bertentangan dan fungsi ansietas adalah mengingatkan ego bahwa ada bahaya.

\section{Teori Interpersonal}

Ansietas timbul dari perasaan takut terhadap tidak adanya penerimaan dari hubungan interpersonal. Ansietas juga berhubungan dengan perkembangan, trauma seperti perpisahan dan kehilangan sehingga menimbulkan kelemahan spesifik.Orang dengan harga diri rendah mudah mengalami perkembangan ansietas yang berat.

\section{Teori Perilaku}

Ansietas merupakan produk frustasi yaitu segala sesuatu yang mengganggu kemampuan seseorang untuk mencapai tujuan yang diinginkan.Daftar tentang pembelajaran meyakini bahwa individu yang terbiasa dalam kehidupan dininya dihadapkan pada ketakutan yng berlebihan lebih sering menunjukkan ansietas pada kehidupan selanjutnya.

\section{Kajian Keluarga}

Menunjukkan bahwa gangguan ansietas merupakan hal yang biasa ditemui dalam suatu keluarga.Ada tumpang tindih dalam gangguan ansietas dan antara gangguan ansietas dengan depresi (Pardede, 20200.

\section{Kajian Biologis}

Menunjukkan bahwa otak mengandung reseptor khusus benzodiazepine. Reseptor ini mungkin membantu mengatur ansietas penghambat dalam aminobutirik. Gamma neuroregulator (GABA) juga mungkin memainkan peran utama dalam mekanisme biologis berhubungan dengan ansietas sebagaimana halnya endorfin. Selain itu telah dibuktikan kesehatan umum seseorang mempunyai akibat nyata sebagai predisposisi terhadap ansietas. Ansietas mungkin disertai dengan gangguan fisik dan selanjutnya menurunkan kapasitas seseorang untuk mengatasi stressor. 


\section{b. Faktor Presipitasi}

Stressor pencetus mungkin berasal dari sumber internal atau eksternal. Stressor pencetus dapat dikelompokkan menjadi 2 kategori :

a) Ancaman terhadap integritas seseorang meliputi ketidakmampuan fisiologis yang akan datang atau menurunnya kapasitas untuk melakukan aktifitas hidup sehari- hari.

b) Ancaman terhadap sistem diri seseorang dapat membahayakan identitas, harga diri dan fungsi sosial yang terintegrasi seseorang.

\section{c. Perilaku}

Kecemasan dapat diekspresikan secara langsung melalui perubahan fisiologi dan perilaku dan secara tidak langsung melalui timbulnya gejala atau mekanisme koping dalam upaya melawan kecemasan. Intensitas perilaku akan meningkat sejalan dengan peningkatan tingkat kecemasan

\section{d. Respon Fisiologis Terhadap Ansietas}

\begin{tabular}{|c|c|}
\hline Kardiovaskuler & $\begin{array}{l}\text { - Palpitasi. } \\
\text { - Jantung berdebar. } \\
\text { - Tekanan darah meningkat dan denyut nadi } \\
\text { menurun. } \\
\text { - Rasa mau pingsan dan pada akhirnya pingsan. }\end{array}$ \\
\hline Pernapasan & $\begin{array}{l}\text { - } \text { Napas cepat. } \\
\text { - Pernapasan dangkal. } \\
\text { - Rasa tertekan pada dada. } \\
\text { - Pembengkakan pada tenggorokan. } \\
\text { - Rasa tercekik. } \\
\text { - Terengah-engah. }\end{array}$ \\
\hline Neuromuskular & $\begin{array}{l}\text { - } \text { Peningkatan reflek. } \\
\text { - Reaksi kejutan. } \\
\text { - Insomnia. } \\
\text { - Ketakutan. } \\
\text { - Gelisah. } \\
\text { - Wajah tegang. } \\
\text { - Kelemahan secara umum. } \\
\text { - Gerakan lambat. } \\
\text { - Gerakan yang janggal. }\end{array}$ \\
\hline Gastrointestinal & $\begin{array}{l}\text { - } \quad \text { Kehilangan nafsu makan. } \\
\text { - } \text { Menolak makan. } \\
\text { - } \text { Perasaan dangkal. } \\
\text { - } \text { Rasa tidak nyaman pada abdominal. } \\
\text { - } \text { Rasa terbakar pada jantung. } \\
\text { - } \quad \text { Diausea } \\
\end{array}$ \\
\hline Perkemihan & - $\quad$ Tidak dapat menahan kencing. \\
\hline
\end{tabular}




\begin{tabular}{|c|c|}
\hline & - Sering kencing. \\
\hline Kulit & $\begin{array}{l}\text { - Rasa terbakar pada mukosa. } \\
\text { - } \text { Berkeringat banyak pada telapak tangan. } \\
\text { - Gatal-gatal. } \\
\text { - } \text { Perasaan panas atau dingin pada kulit. } \\
\text { - Muka pucat dan bekeringat diseluruh tubuh. }\end{array}$ \\
\hline
\end{tabular}

e. Respon Perilaku gangguan citra tubuh

\begin{tabular}{|c|c|}
\hline Sistem & Respons \\
\hline Prilaku & $\begin{array}{l}\text { - } \text { Gelisah. } \\
\text { - Gugup. } \\
\text { - } \text { Bicara cepat. } \\
\text { - Tidak ada koordinasi } \\
\text { - Menarik diri. } \\
\text { - } \text { Menghindar. }\end{array}$ \\
\hline \multirow[t]{2}{*}{ Kognitif } & $\begin{array}{l}\text { - } \text { Gangguan perhatian. } \\
\text { - } \text { Konsentrasi hilang } \\
\text { - } \text { Pelupa. } \\
\text { - Salah tafsir. } \\
\text { - } \text { Adanya bloking pada pikiran } \\
\text { - Kreatif dan produktif menurun. } \\
\text { - } \text { Bingung. } \\
\text { - Sedih }\end{array}$ \\
\hline & $\begin{array}{l}\text { - Khawatir yang berlebihan. } \\
\text { - Hilang menilai objektifitas. } \\
\text { - Takut akan kehilangan kendali. } \\
\text { - } \quad \text { Takut yang berlebihan. } \\
\end{array}$ \\
\hline Afektif & $\begin{array}{l}\text { - } \text { Mudah terganggu } \\
\text { - } \text { Tidak sabar. } \\
\text { - Gelisah. } \\
\text { - } \text { Tegang. } \\
\text { - Nerveus. } \\
\text { - Ketakutan. } \\
\text { - Gugup. } \\
\text { - Gelisah. }\end{array}$ \\
\hline
\end{tabular}

\section{f. Sumber Koping}

Individu dapat mengalami stress dan ansietas dengan menggerakkan sumber koping tersebut di lingkungan. Sumber koping tersebut sebagai modal ekonomok, kemampuan penyelesaian masalah, dukungan sosial dan keyakinan budaya dapat membantu seseorang mengintegrasikan pengalaman yang menimbulkan stress dan mengadopsi strategi koping yang berhasil.

\section{g. Mekanisme Koping}

Ketika mengalami ansietas individu menggunakan berbagai mekanisme koping untuk mencoba mengatasinya dan ketidakmampuan mengatasi ansietas secara 
konstruktif merupakan penyebab utama terjadinya perilaku patologis. Ansietas tingkat ringan sering ditanggulangi tanpa yang serius. Tingkat ansietas sedang dan berat menimbulkan 2 jenis mekanisme koping :

a. Reaksi yang berorientasi pada tugas, yaitu upaya yang disadari dan berorientasi pada tindakan untuk memenuhi secara realitis tuntutan situasi stress.

b. Mekanisme pertahanan ego, membantu mengatasi ansietas ringan dan sedang, tetapi jika berlangsung pada tingkat sadar dan melibatkan penipuan diri dan distorsi realitas, maka mekanisme ini dapat merupakan respon maladaptif terhadap stress.

\subsubsection{Diagnosa Keperawatan}

Adapun diagnosa yang biasanya muncul adalah :

1. Kecemasan

2. Gangguan Citra Tubuh

3. keputusasaan

\subsubsection{Intervensi Keperawatan}

\section{Kecemasan}

\section{Tujuan :}

a. Klien mampu mengenal pengertian penyebab tanda gejala dan akibat

b. Klien mampu mengetahui cara mengatasi ansietas

c. Klien mampu mengatasi ansietas dengan melakukan latihan relaksasi tarik nafas dalam

d. Klien mampu mengatasi ansietas dengan melakukan latihan distraksi

e. Klien mampu mengatasi ansietas dengan melakukan hipnotis lima jari

f. Klien mampu merasakan manfaat dari latihan yang dilakukan

g. Klien mampu membedakan perasaan sebelum dan sesudah latihan

\section{Tindakan :}

a. Kaji tanda dan gejala ansietas dan kemampuan klien mengurangi kecemasan

b. Jelaskan tanda dan gejala, penyebab dan akibat dari kecemasan

c. Latihan cara mengatasi kecemasan :

1) Teknik relaksasi napas dalam

2) Distraksi : bercakap-cakap hal positif 
3) Hipnotis 5 jari fokus padahal-hal yang positif

4) Bantu klien melakukan latihan sesuai dengan jadwal kegiata

\section{Gangguan Citra Tubuh}

\section{Tujuan :}

a. Klien mampu mengenal pengertian penyebab tanda gejala dan akibat

b. Klien mampu mengatasi rasa tidak percaya diri terhadap perubahan pada wajahnya

c. Klien mampu mengatasi perasaan tidak percaya diri dengan beberapa therapi

d. Klien mampu merasakan mamfaat dari latihan yang diajarkan TINDAKAN :

1. Melatih bagian tubuh yang terganggu contoh nya : Fisiotherapy

2. Melatih cara bicara A, I, U, E,O

3. Therapi Genggam Bola

\section{Keputusasaan}

a. Bina hubungan saling percaya dengan menggunakan komunikasi yang terapeutik

b. Klien mampu mengidentifikasi aspek positif dan kemampuan yang di miliki klien, keluarga dan lingkungan

c. Klien mampu menilai kemampuan yang dimiliki untuk dilaksanakan

d. Membantu klien memilih kegiatan yang akan dilatih sesuai dengan kemampuan

e. Melatih klien kegiatan yang dipilih sesuai rencana yang dibuat sesuai kemampuan klien

TINDAKAN :

a. Terapkan dukungan keluarga

b. Kemudian ajarkan pasien untuk mengatakan sugesti positive

c. Bantu klien untuk memikirkan dan melakukan hal hal positive

d. Tingkatkan kegiatan Spritual,keagamaan 


\subsubsection{Implementasi keperawatan}

Merupakan inisiatif dari rencana tindakan untuk mencapai tujuan yang spesifik. Tahap pelaksanaan dimulai dimulai setelah rencana tindakan disusun dan ditujukan pada nursing orders untuk membantu klien mencapai tujuan yang diharapkan. Oleh karena itu rencana tindakan yang spesifik dilaksanakan untuk memodifikasi faktor-faktor yang mempengaruhi masalah kesehatan klien (Stuart, Keliat \& Pasaribu, 2016). Adapun tahap-tahap dalam tindakan keperawatan adalah sebagai berikut :

a. Tahap 1: persiapan Tahap awal tindakan keperawatan ini menuntut perawat untuk mengevaluasi yang diindentifikasi pada tahap perencanaan.

b. Tahap 2: intervensi Focus tahap pelaksanaan tindakan perawatan adalah kegiatan dan pelaksanaan tindakan dari perencanaan untuk memenuhi kebutuhan fisik dan emosional. Pendekatan tindakan keperawatan meliputi tindakan: independen, dependen, dan interdependen.

c. Tahap 3: dokumentasi Pelaksanaan tindakan keperawatan harus diikuti oleh pencatatan yang lengkap dan akurat terhadap suatu kejadian dalam proses keperawatan.

\subsubsection{Evaluasi}

Keberhasilan tindakan keperawatan. Keberhasilan proses dapat dilihat dengan jalan membandingkan antara proses dengan pedoman/rencana proses tersebut. Perencanaan evaluasi memuat criteria keberhasilan proses dan Sedangkan keberhasilan tindakan dapat dilihat dengan membandingkan antara tingkat kemandirian pasien dalam kehidupan sehari-hari dan tingkat kemajuan kesehatan pasien dengan tujuan yang telah di rumuskan sebelumnya. Sasaran evaluasi adalah sebagai berikut:

a. Proses asuhan keperawatan, berdasarkan criteria/ rencana yang telah disusun.

b. Hasil tindakan keperawatan, berdasarkan criteria keberhasilan yang telah di rumuskan dalam rencana evaluasi.

c. Hasil evaluasi Terdapat 3 kemungkinan hasil evaluasi yaitu :

1) Tujuan tercapai, apabila pasien telah menunjukan perbaikan/ kemajuan sesuai dengan criteria yang telah di tetapkan. 
2) Tujuan tercapai sebagian, apabila tujuan itu tidak tercapai secara maksimal, sehingga perlu di cari penyebab dan cara mengatasinya.

3) Tujuan tidak tercapai, apabila pasien tidak menunjukan perubahan/kemajuan sama sekali bahkan timbul masalah baru.dalam hal ini perawat perlu untuk mengkaji secara lebih mendalam apakah terdapat data, analisis, diagnosa, tindakan, dan faktor-faktor lain yang tidak sesuai yang menjadi penyebab tidak tercapainya tujuan.

Setelah seorang perawat melakukan seluruh proses keperawatan dari pengkajian sampai dengan evaluasi kepada pasien, seluruh tindakannya harus di dokumentasikan dengan benar dalam dokumentasi keperawatan.

$\begin{array}{llll}\text { (Stuart, } & \text { keliat } & \& & \text { 2016) }\end{array}$ 
BAB 3

\section{TINJAUAN KASUS}

\subsection{PENGKAJIAN KEPERAWATAN}

\begin{tabular}{|c|c|}
\hline $\begin{array}{l}\text { Nama : Ny E } \\
\text { Usia : } 25 \text { tahun } \\
\text { Tahun no reg : - } \\
\text { Ruangan : - } \\
\text { Tgl masuk rs: - } \\
\text { Tgl pengkajian : } 7 \text { oktober } 2021 \\
\text { Alamat : Jalan Amal Luhur kec medan helvetia }\end{array}$ & $\begin{array}{l}\text { Kondisi saat MRS: Pasien mengatakan separuh mukanya } \\
\text { turun dan sulit untuk berbicara dan juga menelan makanan . } \\
\text { Kondisi saat ini : } \\
\text { Ny. E mengeluh wajahnya sebelah kiri sulit untuk di gerakan dan } \\
\text { sulit juga untuk berbicara, pasien mengatakan sangat malu dan tidak } \\
\text { mau bertemu siapapun dikarenakan kondisi wajahnya.dan juga } \\
\text { merasa stres atas apa yang ia hadapi. }\end{array}$ \\
\hline
\end{tabular}

\subsubsection{FAKTOR PREDISPOSISI DAN FAKTOR PRESIPITASI}

\begin{tabular}{|c|c|c|c|c|c|}
\hline \multirow{2}{*}{\multicolumn{2}{|c|}{ Faktor predisposisi }} & \multicolumn{3}{|l|}{ Faktor presipitasi } & \multirow[t]{2}{*}{ STRESSOR } \\
\hline & & Nature & \multirow{2}{*}{$\begin{array}{l}\text { Origin } \\
\text { Internal }\end{array}$} & \multirow{2}{*}{$\begin{array}{l}\begin{array}{l}\text { Number } \quad \& \\
\text { Timing }\end{array} \\
\begin{array}{l}\text { Sejak 2 bulan } \\
\text { yang lalu }\end{array}\end{array}$} & \\
\hline Biologis: & $\begin{array}{l}\text { 1. Bells Palsy } \\
\text { 2. Ny. E menderita Bells Palsy } \\
2 \text { Bulan yang lalu } \\
\text { 3. Ny. E sering menggunakan } \\
\text { kipas angin dan sering } \\
\text { terpapar dingin. } \\
\text { 4. Ny. E rutin check up } \\
\text { kepelayanan kesehatan }\end{array}$ & 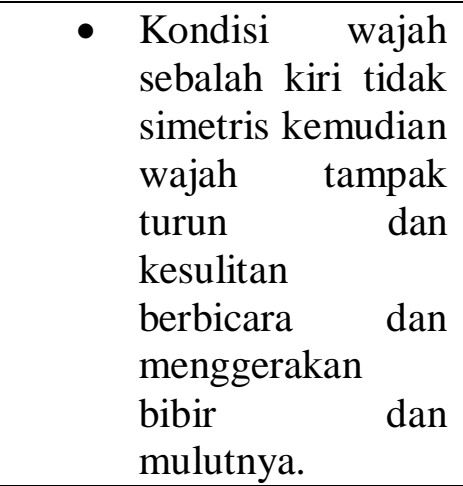 & & & - Bells Palsy \\
\hline Psikologis : & & $\begin{array}{l}\text { - Takut, gelisah, } \\
\text { dan putus asa }\end{array}$ & Internal & $\begin{array}{lr}\text { Sejak } & 3 \\
\text { minggu } & \text { yang } \\
\end{array}$ & $\begin{array}{l}\text { - Cemas, takut, panik, khawatir, } \\
\text { gelisah }\end{array}$ \\
\hline
\end{tabular}




\begin{tabular}{|c|c|c|c|}
\hline $\begin{array}{l}\text { 1. Ny. E memiliki kepribadian yang } \\
\text { tertutup dan tidak mau bertemu orang } \\
\text { banyak. } \\
\text { 2. Ny. E merasa tidak bisa menggerakan } \\
\text { sebelah wajahnya,kesulitan makan. }\end{array}$ & $\begin{array}{l}\text { bagaimana jika } \\
\text { penyakit ini tidak } \\
\text { sembuh. } \\
\text { - Sering kepikiran } \\
\text { penyakitnya. }\end{array}$ & lalu & \\
\hline $\begin{array}{l}\text { Sosiocultural : } \\
\text { 1. Ny. E seorang perempuan umur } 25 \\
\text { tahun } \\
\text { 2. Ny. E Belum menikah } \\
\text { 3. Ny.E merupakan ibu rumah tangga } \\
\text { 4. Sebelumnya Ny. E Tidak begitu aktif } \\
\text { terlibat dalam } \\
\text { Kemahasiswaan } \\
\text { 5. Ny.E merupakan orang jawa dan } \\
\text { menurut Ny.E tidak ada kebiasaan } \\
\text { yang bertentangan dengan kesehatan. } \\
\text { 6. Ny.E beragama islam dan taat } \\
\text { menjalankan ibadah } \\
\text { 7. Ny.E Rutin check up penyakitnya }\end{array}$ & - & & • \\
\hline
\end{tabular}




\section{GENOGRAM}

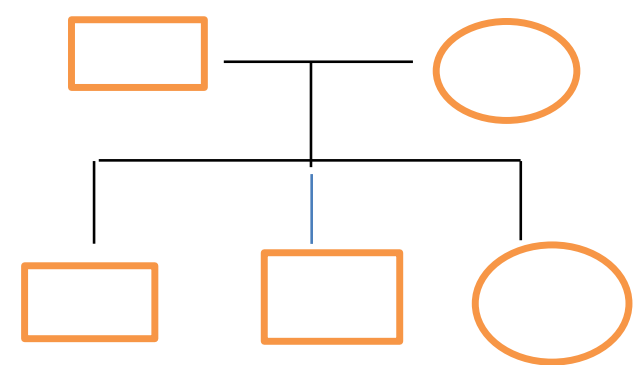

Ny. E Memiliki keluarga dikampung terdiri dari orangtua dan dua orang kakak laki . 


\subsubsection{PENILAIAN (RESPON)TERHADAP STRESSOR}

\begin{tabular}{|c|c|c|c|c|c|c|}
\hline STRESSOR & KOGNITIF & AFEKTIF & FISIOLOGIS & PERILAKU & SOSIAL & $\begin{array}{l}\text { DIAGNOSA } \\
\text { KEPERAWATAN }\end{array}$ \\
\hline $\begin{array}{l}\text { BIOLOGIS } \\
\text { • Bells Palsy }\end{array}$ & $\begin{array}{l}\text { - Menurut Ny.E } \\
\text { dia menderita } \\
\text { penyakit ini } \\
\text { dikarenakan } \\
\text { sering terpapar } \\
\text { angin dan kata } \\
\text { dokter } \\
\text { disebabkan } \\
\text { oleh infeksi } \\
\text { virus dan juga } \\
\text { disebabkan } \\
\text { stress } \\
\text { berlebihan. } \\
\text { Menganggap } \\
\text { penyakit } \\
\text { yang diderita } \\
\text { tidak akan } \\
\text { bias sembuh } \\
\text { Tidak tahu apa } \\
\text { yang harus } \\
\text { dilakukan } \\
\text { untuk tidak } \\
\text { penyakitnya } \\
\text { karena sudah } \\
\text { berapa kali } \\
\text { terapi kunjung } \\
\text { sembuh. }\end{array}$ & $\begin{array}{l}\text { - } \text { Ny.E merasa } \\
\text { sedih dan } \\
\text { bingung } \\
\text { dengan } \\
\text { kondisi } \\
\text { penyakitnya } \\
\text { dan kerap } \\
\text { kali } \\
\text { menangis. }\end{array}$ & $\begin{array}{l}\text { - Sulit tidur } \\
\text { - Tidak nafsu } \\
\text { makan } \\
\text { - Ny. E tampak } \\
\text { lemas } \\
\text { - Pemeriksaan } \\
\text { TTV } \\
\text { TD: 90/70 } \\
\text { Mmhg }\end{array}$ & $\begin{array}{l}\text { - } \text { Ny.E rutin } \\
\text { ke rumah } \\
\text { sakit } \\
\text { - Ekspresi } \\
\text { muka lesu } \\
\text {,lemas } \\
\text { - Ny.E tampak } \\
\text { diam dan } \\
\text { kadang ingin } \\
\text { menangis }\end{array}$ & $\begin{array}{l}\text { - Pasien } \\
\text { mendatangi } \\
\text { dan } \\
\text { menggunaka } \mathrm{n} \\
\text { fasilitas } \\
\text { kesehatan yang } \\
\text { ada untuk } \\
\text { mencari } \\
\text { kesembuhan } \\
\text { terhadap } \\
\text { masalah yang } \\
\text { dihadapi saat } \\
\text { ini }\end{array}$ & - Ansietas \\
\hline
\end{tabular}




\begin{tabular}{|c|c|c|c|c|c|c|}
\hline $\begin{array}{l}\text { PSIKOLOGIS } \\
\text { - sedih, cemas, } \\
\text { kesal dan } \\
\text { Bingung } \\
\text { dengan kondisi } \\
\text { penyakit dan } \\
\text { Penyemb } \\
\text { uhannya } \\
\text { yang } \\
\text { begitu } \\
\text { lama, } \\
\text { serta } \\
\text { Perawatannya }\end{array}$ & $\begin{array}{l}\text { - Ny. E tahu } \\
\text { bahwa } \\
\text { Wajahnya } \\
\text { menurun dan } \\
\text { tidak bias di } \\
\text { gerakan } \\
\text { - Ny. E } \\
\text { mengaku } \\
\text { Sangat sedih } \\
\text { dan tidak } \\
\text { ingin bertemu } \\
\text { dengan } \\
\text { siapapun dan } \\
\text { sangat malu } \\
\text { ketka bertemu } \\
\text { dengan orang } \\
\text { banyak. }\end{array}$ & $\begin{array}{l}\text { - Merasa kesal } \\
\text { dan putus asa } \\
\text { dengan } \\
\text { penyakitnya } \\
\text { yang tidak } \\
\text { sembuh- } \\
\text { sembuh } \\
\text { padahal sudah } \\
\text { beberapa } \\
\text { bulan. }\end{array}$ & $\begin{array}{l}\text { - Pusing } \\
\text { - Nyeri sedang } \\
\text { - Sulit tidur dan } \\
\text { sering } \\
\text { terbangun } \\
\text { apabila tidur } \\
\text { - Kepala dan } \\
\text { belakang } \\
\text { telinga terasa } \\
\text { sakit. } \\
\text { - Tidak nafsu } \\
\text { makan } \\
\text { - Ny.A tampak } \\
\text { lemas } \\
\text { - Wajah Ny.E } \\
\text { tampak tidak } \\
\text { simetris dan } \\
\text { turun. } \\
\text { - Wajah Ny. E } \\
\text { tampak pucat. } \\
\text { - Pemeriksaan } \\
\text { TTV } \\
\text { TD: } 90 / 70 \\
\text { mmhg } \\
\mathrm{N}: 88 \mathrm{x} / \text { menit } \\
\mathrm{P}: 20 \mathrm{x} / \mathrm{menit} \\
\mathrm{S}: 366^{0} \mathrm{C}\end{array}$ & $\begin{array}{l}\text { - Tampak } \\
\text { cemas dan } \\
\text { tidak } \\
\text { tenang } \\
\text { - Kadang } \\
\text { Ny.E } \\
\text { tampak } \\
\text { murung } \\
\text { - Ny.E } \\
\text { tampak } \\
\text { gelisah } \\
\text { - Ny.E } \\
\text { tampak } \\
\text { aktif dalam } \\
\text { menerima } \\
\text { perawatan } \\
\text { Ny.E } \\
\text { menunduk } \\
\text { saat bercerita } \\
\text { dan jarang ada } \\
\text { kontak mata. }\end{array}$ & $\begin{array}{l}\text { - Hubungan } \\
\text { Ny.E dengan } \\
\text { keluarga baik } \\
\text { - Ny.E kurang } \\
\text { bersosialisasi } \\
\text { dengan } \\
\text { keluarga } \\
\text { Ny.E tetap } \\
\text { mengikuti } \\
\text { program } \\
\text { pengobatan } \\
\text { yang diberikan } \\
\text { kepadanya } \\
\text { akan tetapi } \\
\text { tidak begitu } \\
\text { antusias dan } \\
\text { Ny.E dalam } \\
\text { menerima } \\
\text { perawatan }\end{array}$ & - gangguan citra tubuh \\
\hline
\end{tabular}




\begin{tabular}{|c|c|c|c|c|c|c|}
\hline 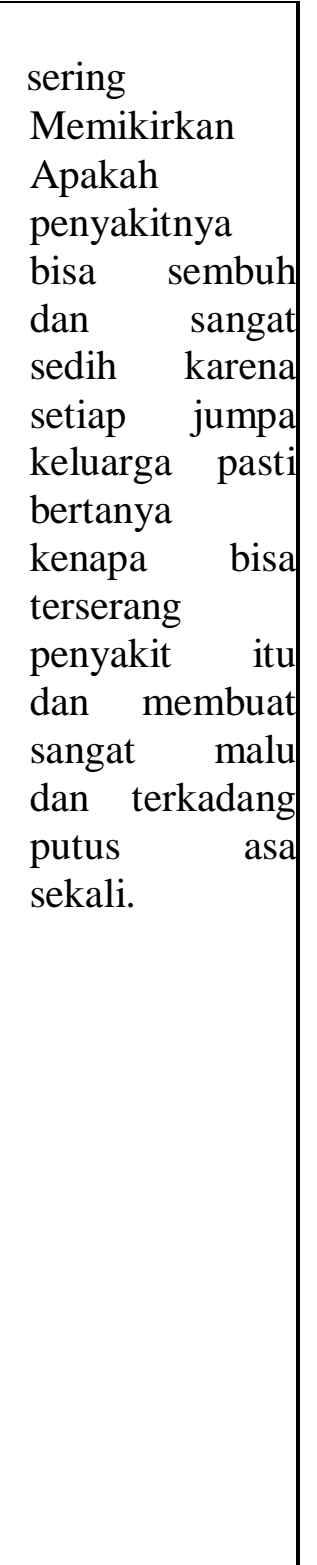 & $\begin{array}{l}\text { - Ny.A merasa } \\
\text { tidak berdaya } \\
\text { dengan } \\
\text { keadaannya } \\
\text { sejarang yang } \\
\text { tidak bias } \\
\text { mengunyah } \\
\text { dengan baik } \\
\text { begitu juga } \\
\text { ketika akan } \\
\text { tersenyum dan } \\
\text { berbicara. } \\
\text { - Ny.E berfikir } \\
\text { ia selalu } \\
\text { merepotkan } \\
\text { kluarga } \\
\text { karena biaya } \\
\text { pengobatan } \\
\text { yang begitu } \\
\text { banyak. } \\
\text { Keluarganya } \\
\text { juga panik bila } \\
\text { terlalu lama } \\
\text { dalam keadaan } \\
\text { seperti ini } \\
\text { merasa } \\
\text { Kasihan } \\
\text { Kepada } \\
\text { keluarga } \\
\text { yang harus } \\
\text { menangani } \\
\text { biaya terapi }\end{array}$ & $\begin{array}{l}\text { - Merasa } \\
\text { khawatir dan } \\
\text { sedih kepada } \\
\text { dirinya } \\
\text { sendiri. } \\
\text { - Merasa } \\
\text { bersalah } \\
\text { karena } \\
\text { merasa } \\
\text { merepotkan } \\
\text { keluarga } \\
\text { Merasa } \\
\text { bosan } \\
\text { dengan } \\
\text { keadaan } \\
\text { sekarang } \\
\text { yang tidak } \\
\text { kunjung } \\
\text { membaik. }\end{array}$ & $\begin{array}{l}\text { - } \text { Pusing } \\
\text { - } \text { bibir tampak } \\
\text { kering } \\
\text { - } \text { mata cekung } \\
\text { - Sulit tidur } \\
\text { - kepala terasa } \\
\text { tegang } \\
\text { - Tidak nafsu } \\
\text { makan } \\
\text { - Ny.E tampak } \\
\text { lemas } \\
\text { - Wajah Ny.E } \\
\text { tampak pucat } \\
\text { Seperti } \\
\text { kekurangan } \\
\text { darah. }\end{array}$ & $\begin{array}{l}\text { - Kontak mata } \\
\text { ada tapi tidak } \\
\text { bertahan } \\
\text { lama dan } \\
\text { sering } \\
\text { menunduk } \\
\text { - Volume } \\
\text { suara } \\
\text { mengecil } \\
\text { - Ny.E tampak } \\
\text { gelisah Dan } \\
\text { khawatir. }\end{array}$ & $\begin{array}{l}\text { - Hubungan } \\
\text { Ny.E dengan } \\
\text { keluarga baik } \\
\text { - Hubungan } \\
\text { Ny. E dengan } \\
\text { petugas } \\
\text { kesehatan } \\
\text { baik } \\
\text { - Ny. E tetap } \\
\text { mengikuti } \\
\text { program } \\
\text { pengobatan } \\
\text { Dan terus } \\
\text { menjalani } \\
\text { terapi. }\end{array}$ & - Keputusasaan \\
\hline
\end{tabular}




\subsubsection{SUMBER KOPING}

\begin{tabular}{|c|c|c|c|c|c|}
\hline $\begin{array}{l}\text { DIAGNOSA } \\
\text { KEPERAWATAN }\end{array}$ & PERSONAL ABILITY & $\begin{array}{l}\text { SOSIAL } \\
\text { SUPPORT }\end{array}$ & $\begin{array}{l}\text { MATERIAL } \\
\text { ASSETS }\end{array}$ & $\begin{array}{l}\text { POSITIE } \\
\text { BELIEFS }\end{array}$ & TERAPI \\
\hline Ansietas & $\begin{array}{l}\text { - Ny. E mampu } \\
\text { mengungkapkan } \\
\text { perasaan cemas } \\
\text { - Ny.E mengatakan } \\
\text { bila cemasnya } \\
\text { memuncak maka } \\
\text { ia akan } \\
\text { mengambil air } \\
\text { wudhu dan sholat } \\
\text { - NyE }\end{array}$ & $\begin{array}{l}\text { Ny. E } \\
\text { mendapat } \\
\text { dukungan dari } \\
\text { keluarga untuk } \\
\text { kesembuhanny } \\
\text { a terutama dari } \\
\text { suaminya } \\
\text { - Suami dan adik } \\
\text { Ny.E bergantian } \\
\text { merawat pasien }\end{array}$ & $\begin{array}{l}\text { - Sosial ekonomi Ny. } \\
\text { A menengah } \\
\text { Pengobatan } \\
\text { ditanggung BPJS } \\
\text { - Jarak rumah Ny.S } \\
\text { dengan tempat } \\
\text { pelayanan kesehatan } \\
\text { lebih kurang } 500 \\
\text { meter }\end{array}$ & $\begin{array}{l}\text { - Ny.Spercaya } \\
\text { bahwa petugas } \\
\text { kesehatan akan } \\
\text { membantunya } \\
\text { - Ny. E berharap } \\
\text { cepat sembuh } \\
\text { agar tidak } \\
\text { merepotkan } \\
\text { Suaminya }\end{array}$ & \begin{tabular}{|c} 
Terapi spesialis: \\
- $\begin{array}{l}\text { Relaksasi } \\
\text { progresif }\end{array}$ \\
- $\begin{array}{l}\text { Psikoedu } \\
\text { kasi } \\
\text { keluarga }\end{array}$ \\
- Behavior \\
therapy \\
- $\quad$ Psikoed \\
ukasi \\
keluarga \\
- $\begin{array}{l}\text { Terapi } \\
\text { prilakuk } \\
\text { ognitif }\end{array}$
\end{tabular} \\
\hline
\end{tabular}




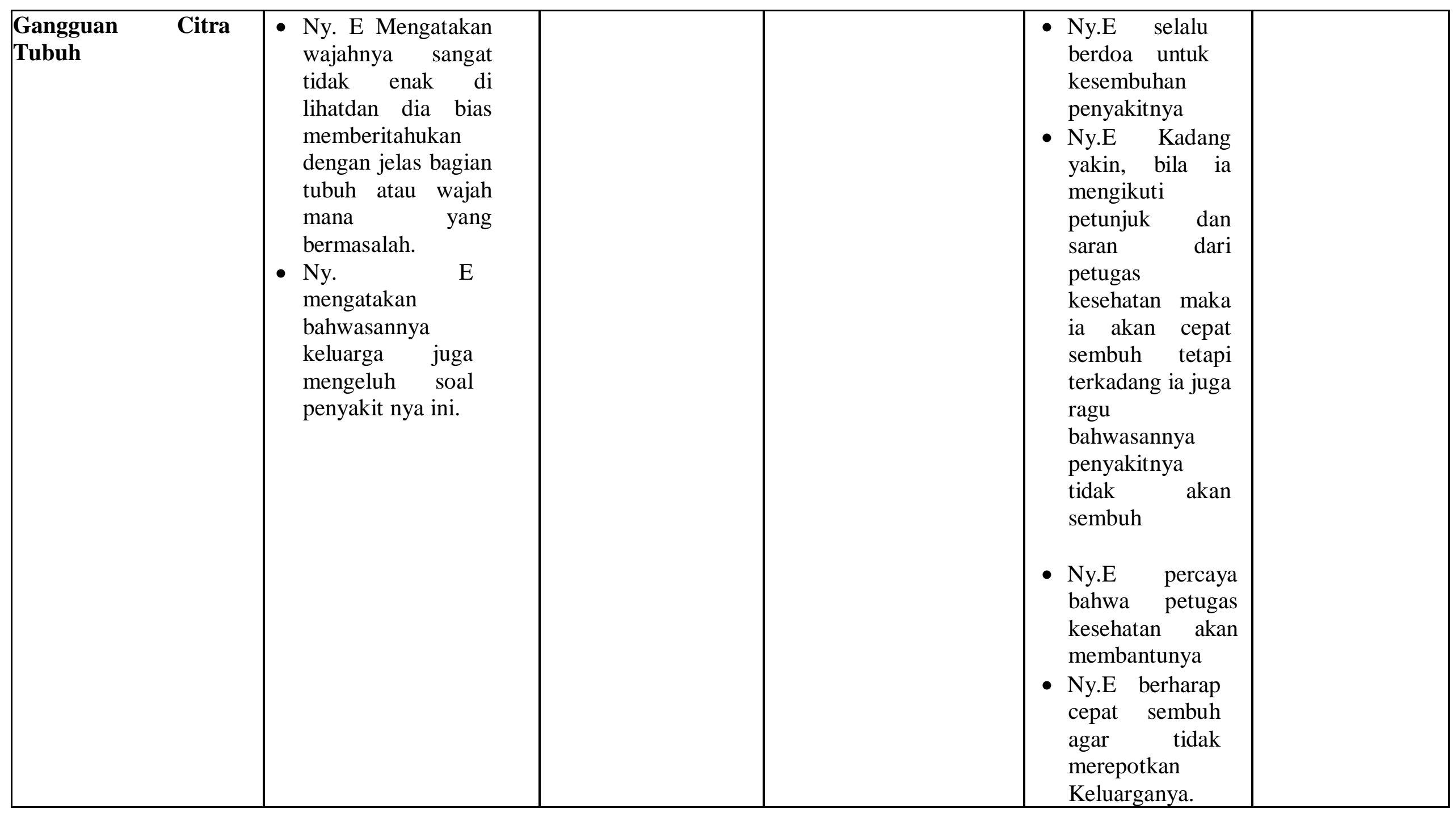




\begin{tabular}{|c|c|c|c|c|}
\hline Keputusasaan & $\begin{array}{l}\text { - Ny. E Tidak mampu } \\
\text { mengenal dan menilai } \\
\text { Komplikasi dari } \\
\text { penyakitnya. } \\
\text { - Ny. E tidak mampu } \\
\text { melatih cara hidup } \\
\text { sehat. }\end{array}$ & $\begin{array}{l}\text { - Ny.E Tidak } \\
\text { mendapat } \\
\text { dukungan dari } \\
\text { keluarga untuk } \\
\text { kesembuhannya } \\
\text { - Ayah dan ibu Ny. } \\
\text { E bergantian } \\
\text { mengantarpasien } \\
\text { terapi. }\end{array}$ & $\begin{array}{l}\text { - } \text { Sosial ekonomi } \\
\text { Ny.E menengah } \\
\text { - Ny.E tinggal di } \\
\text { Kontrakan sendiri, } \\
\text { - Sarana dan } \\
\text { prasarana } \\
\text { tersedia } \\
\text { - } \text { Biaya } \\
\text { pengobatan } \\
\text { ditanggung } \\
\text { asuransi BPJS } \\
\text { dan untuk fisiotherapi } \\
\text { khusus langsung ke } \\
\text { ahlinya } \\
\text { menggunakan dana } \\
\text { pribadi. }\end{array}$ & $\begin{array}{l}\text { - Ny.E percaya } \\
\text { bahwa petugas } \\
\text { kesehatan akan } \\
\text { membantunya } \\
\text { - Ny.E berharap } \\
\text { cepat sembuh } \\
\text { agar tidak } \\
\text { merepotkan } \\
\text { Keluarganya. } \\
\text { - Ny.E selalu } \\
\text { berdoa untuk } \\
\text { kesembuhan } \\
\text { penyakitnya } \\
\text { Ny.E yakin, } \\
\text { bila ia } \\
\text { mengikuti } \\
\text { petunjuk dan } \\
\text { saran dari } \\
\text { petugas } \\
\text { kesehatan } \\
\text { maka ia akan } \\
\text { cepat sembuh } \\
\text { - Ny.E Tidak } \\
\text { yakin keluarga } \\
\text { mendukung } \\
\text { supaya lekas } \\
\text { sembuh. }\end{array}$ \\
\hline
\end{tabular}




\subsubsection{MEKANISME KOPING}

\begin{tabular}{|c|c|}
\hline $\begin{array}{l}\text { HAL } \\
\text { DILAKUKAN }\end{array}$ & ANALISA \\
\hline $\begin{array}{l}\text { - Ny.E mengatakan bila ada masalah, maka ia akan membicarakan } \\
\text { dengan Keluarga untuk mencari jalan keluarnya } \\
\text { - Bila sakit Ny.E berobat ke pelayanan kesehatan } \\
\text { - Ny.E taat menjalankan ibadah sesuai dengan keyakinannya } \\
\text { - Ny.E selalu berdoa kepada Allah SWT untuk kesembuhannya. } \\
\text { - Ny E Kurang mau bertemu orang banyak. }\end{array}$ & $\begin{array}{l}\text { - Konstruktif: } \\
\checkmark \text { Ny.E mengatakan bila ada masalah Iya pendam sendiri. } \\
\checkmark \text { Bila sakit Ny.E berobat ke pelayanan kesehatan } \\
\checkmark \text { Ny.E taat menjalankan ibadah sesuai dengan } \\
\text { keyakinannya } \\
\checkmark \text { Ny.E selalu berdoa kepada Allah SWT untuk } \\
\text { kesembuhannya. } \\
\text { - Destruktif : - }\end{array}$ \\
\hline
\end{tabular}




\begin{tabular}{|c|c|}
\hline 1. Penampilan & Bersih, rapi, tidak tercium bau, Ny.E tampak lemas \\
\hline 2. Pembicaraan & Susah berbicara akibat dari kelumpuhan sebelah dari anggota tubuh (afasia ) \\
\hline 3. Aktivitas motoric & Wajah sulit digerakkan \\
\hline 4. Interaksi selama wawancara & Cukup kooperatif, meskipun afasia \\
\hline 5. Alam perasaan & Sedih, merasa cemas ,takut dan bingung mengenai kondisi penyakit, suami dan anak-anaknya tidak percaya diri. \\
\hline 7. Persepsi & Ny.E mengalami gangguan dalam proses sensori-persepsi \\
\hline 8. Isi piker & Mengalami masalah karena seering merasa putus asa dan malu \\
\hline 9. Proses piker & masalah karena sering kali emosi tidak terkontrol. \\
\hline 10. Tingkat kesadaran & Normal dan bias mengenali semua orang \\
\hline 13. Penilaian & Ny.E belum mampu menyebutkan bagaimana caranya agar Ny.E Bisa sembuh \\
\hline 14. Daya tilik diri & $\begin{array}{l}\text { Ny.E menyadari bahwa saat ini ia sdang sakit, Ny.E hanya bisa berdoa supaya lekas sembuh agar tidak } \\
\text { terus merepotkan Keluarganya Ny.E menyadari ia Masih menjadi beban, keluarga yang menyayanginya } \\
\text { dan mendukung kesembuhannya }\end{array}$ \\
\hline
\end{tabular}

Kesimpulan : Mental Status Examination (MSE) tidak ada masalah gangguan jiwa, gangguan Ny. E lebih kepada Gangguan Mental Emosional (GME/Psikososial) 


\section{DIAGNOSA KEPERAWATAN DAN TERAPI KEPERAWATAN}

Sp1: mendiskusikan penyebab,terjadinya proses terjadi, tanda gejala,akibat

$$
\begin{aligned}
& \text { Sp2 :melatih teknik releksasi fisik } \\
& \text { Sp3:melatih mengatasi ansietas dengan } \\
& \text { distraksi dan hipnotis lima } \\
& \text { Sp4 : melatih mengatasi ansietas memalui } \\
& \text { kegiatan spritual }
\end{aligned}
$$

2. Gangguan Citra Tubuh

Sp $1:$ Sp 1

Identifikasi citra tubuh pasien dulu dan saat ini, perasaan

dan harapan tubuhnya saat ini.

Identifikasi aspek positive pasien

Ajarkan pasien cara melatih bagian tubuh yang terganggu

Masukan dalam jadwal kegiatan harian

Sp 2

Latih intreaksi secara bertahap

( Jadwal kegiatan sehari sehari bersama keluarga, teman dan orang orang yang mempunyai peran penting)

3. Keputusasaan

Sp 1

a. Bantu klien untuk mengidentifikasi dan menguraikan perasaan sedihnya dan keputusasaanya

b. Bantu klien klien mengenal penyebab putus asa

c. Bantu klien mengetahui penyebab putus asa

d. Dukung klien mengungkapkan perasaan posititive dan pengalamannya

\section{DIAGNOSA MEDIS}

Bells Palsy 
a. Latih retruksiasi pikiran melalui pikiran positive

\subsection{IMPLEMENTASI TINDAKAN KPERAWATAN DAN EVALUASI}

\begin{tabular}{|c|c|}
\hline IMPLEMENTASI TINDAKAN KPERAWATAN & EVALUASI \\
\hline $\begin{array}{l}\text { 1. Memberi salam } \\
\text { 2. Menenangkan pasien } \\
\text { 3. Memahami keadaan pasien } \\
\text { 4. Mendiskusikan penyebab,terjadinya kecemasan, } \\
\text { tanda gejala, serta akibat. } \\
\text { 5. Mengkaji tingkat ansietas } \\
\text { 6. Melatih pasien teknik relaksasi fisik tarik nafas } \\
\text { dalam. } \\
\text { 7. Melatih pasien mengatasi ansietas dengan hipnotis } \\
\text { lima jari } \\
\text { - Atur posisi klien senyaman mungkin } \\
\text { - Instruksikan pada klien untuk memejamkan } \\
\text { mata } \\
\text { - Tarik nafas hembuskan perlahan lahan } \\
\text { sebanyak } 3 \text { x } \\
\text { - Tautkan ibu jari pada telunjuk dan instruksi kan } \\
\text { pada pasien untuk membayangkan tubuh yang } \\
\text { sehat. } \\
\text { - Tautkan ibu jari pada telunjuk dan instruksi kan } \\
\text { pada pasien untuk membayangkan orang yang } \\
\text { disayang } \\
\text { - Tautkan ibu jari pada telunjuk dan instruksi kan } \\
\text { pada pasien untuk membayangkan ketika anda } \\
\text { mendapat penghargaan }\end{array}$ & $\begin{array}{l}\text { S : Senang } \\
\text { O : Pasien mampu melakukan relaksasi nafas dalam. } \\
\text { Pasien mampu melakukan hipnotis } 5 \text { jari dengan bantuan } \\
\text { A: Ansietas (+) } \\
\text { P : Latih cara mengatasi cemas } \\
\text { e. Tekhnik relaksasi nafas dalam } \\
\text { f. } \quad \text { Distraksi : bercakap cakap positive } \\
\text { gengan orang lain (2 Kali sehari) } \\
\text { g. Hipnotis } 5 \text { jari } \\
\text { 3. Ajarkan kegiatan keagamaan untuk meningkatkan } \\
\text { spritual keluarga dan tetap anjurkan keluarga } \\
\text { 4. Libatkan keluargan } \\
\text { mensupport pasien }\end{array}$ \\
\hline
\end{tabular}


- Tautkan ibu jari pada telunjuk dan instruksi kan pada pasien untuk membayangkan

- Intruksikan pada klien untuk tarik nafas dan hembuskan pelan-pelan

- Intruksikan untuk membuka mata perlahan lahan

8. Mengkaji kegiatan spritual pasien

- Apakah pasien rajin ikut pengajian

- Apakah tepat waktu dalam beribadah

9. Mendukung keterlibatan keluarga dengan cara yang tepat

10. Mendukung dan mensupport pasien

Tanggal : 13 Oktober 2021 Jam : $14.00-15.20 \mathrm{wib}$

Dx : Ansietas

1. Memberi salam

2. Menenangkan pasien

3. Memahami keadaan pasien

4. Mendiskusikan penyebab,terjadinya kecemasan, tanda gejala, serta akibat.

5. Mengkaji tingkat ansietas

6. Melatih pasien teknik relaksasi fisik tarik nafas dalam.

7. Melatih pasien mengatasi ansietas dengan ditraksi dan hipnotis lima jari

- Atur posisi klien senyaman mungkin

- Instruksikan pada klien untuk memejamkan mata

- Tarik nafas hembuskan perlahan lahan sebanyak $3 \mathrm{x}$

- Tautkan ibu jari pada telunjuk dan instruksi kan pada pasien untuk membayangkan tubuh yang sehat.

\section{S: Senang}

O :

Pasien mengatakan mampu melakukan relaksasi nafas dalam

Pasien melakukan relaksasi nafas dalam secara mandiri

\section{A: Ansietas (-)}

P :

Latih cara mengatasi cemas

h. Tekhnik relaksasi nafas dalam (2 kali sehari)

i. Distraksi : bercakap cakap positive (2 Kali sehari)

j. Hipnotis 5 jari

5. Ajarkan kegiatan keagamaan untuk meningkatkan spritual

Libatkan keluarga dan tetap anjurkan keluarga mensupport pasien 
- Tautkan ibu jari pada telunjuk dan instruksi kan pada pasien untuk membayangkan orang yang disayang

- Tautkan ibu jari pada telunjuk dan instruksi kan pada pasien untuk membayangkan ketika anda mendapat penghargaan

- Tautkan ibu jari pada telunjuk dan instruksi kan pada pasien untuk membayangkan

- Intruksikan pada klien untuk tarik nafas dan hembuskan pelan-pelan

- Intruksikan untuk membuka mata perlahan lahan

8. Mengkaji kegiatan spritual pasien

- Apakah pasien rajin ikut pengajian

- Apakah tepat waktu dalam beribadah

9. Mendukung keterlibatan keluarga dengan cara yang tepat

10. Mendukung dan mensupport pasien

Tanggal : 14 Oktober 2021

Jam : $14.00-15.20 \mathrm{wib}$

Dx : gangguan citra tubuh

1. Memberi salam

2. Membina hubungan saling percaya

3. Sp 1

Identifikasi citra tubuh pasien dulu dan saat ini, perasaan dan harapan tubuhnya saat ini.

Identifikasi aspek positive pasien

Ajarkan pasien cara melatih bagian tubuh yang terganggu

Masukan dalam jadwal kegiatan harian

4. Sp 2

Latih intreaksi secara bertahap
$\mathbf{S}:$ tidak percaya diri

O :

Pasien mengatakan bahwa mampu mengidenntifikasi citra tubuhnya yang dulu dan yang sekarang

Pasien mampu melatih bagian tubuh yang terganggu

Pasien mampu mengerjakan jadwal kegiatan harian.

A : Keputusasaan (+)

$\mathbf{P}$ : latih pasien untuk

a. Latih pasien mengidentifikasi citra tubuhnya 


\begin{tabular}{|c|c|}
\hline $\begin{array}{l}\text { ( Jadwal kegiatan sehari sehari bersama keluarga, teman dan orang orang } \\
\text { yang mempunyai peran penting) }\end{array}$ & $\begin{array}{l}\text { b. Latih pasien melatih bagian tubuh yang terganggu } \\
\text { c. Latih pasien untuk mengerjakan kegiatan harian } \\
\text { dengan rutin }\end{array}$ \\
\hline $\begin{array}{l}\text { Tanggal : } 15 \text { Oktober } 2021 \\
\text { Jam : } 14.00 \text { - } 15.20 \text { wib } \\
\text { Dx : gangguan citra tubuh } \\
\text { 1. Memberi salam } \\
\text { 2. Membina hubungan saling percaya } \\
\text { 3. Sp } 1 \\
\text { Identifikasi citra tubuh pasien dulu dan saat ini, perasaan dan harapan } \\
\text { tubuhnya saat ini. } \\
\text { Identifikasi aspek positive pasien } \\
\text { Ajarkan pasien cara melatih bagian tubuh yang terganggu } \\
\text { Masukan dalam jadwal kegiatan harian } \\
\text { 4. Sp } 2 \\
\text { Latih intreaksi secara bertahap } \\
\text { ( Jadwal kegiatan sehari sehari bersama keluarga, teman dan orang orang } \\
\text { yang mempunyai peran penting) }\end{array}$ & $\begin{array}{l}\text { S : tidak percaya diri } \\
\text { O : Pasien mengatakan bahwa mampu mengidenntifikasi } \\
\text { citra tubuhnya yang dulu dan yang sekarang } \\
\text { Pasien mampu melatih bagian tubuh yang terganggu } \\
\text { Pasien mampu mengerjakan jadwal kegiatan harian } \\
\text { Pasien mampu melakukan kegiatan harian } \\
\text { A : gangguan citra tubuh (-) } \\
\text { P : latih pasien untuk } \\
\text { a. Latih pasien mengidentifikasi citra tubuhnya } \\
\text { b. Latih pasien melatih bagian tubuh yang terganggu } \\
\text { c. Latih pasien untuk mengerjakan kegiatan harian } \\
\text { dengan rutin } \\
\text { d. Latih intreaksi secara bertahap } \\
\text { ( Jadwal kegiatan sehari sehari bersama } \\
\quad \text { keluarga, teman dan orang orang yang } \\
\text { mempunyai peran penting) }\end{array}$ \\
\hline $\begin{array}{l}\text { Tanggal : } 16 \text { Oktober } 2021 \\
\text { Jam : } 14.00-15.20 \mathrm{wib}\end{array}$ & S : Sedih \\
\hline
\end{tabular}




\begin{tabular}{|c|c|}
\hline $\begin{array}{l}\text { Dx : Keputusasaan } \\
\text { 1. Memberi salam } \\
\text { 2. Membina hubungan saling percaya } \\
\text { 3. Memahami keadaan pasien } \\
\text { 4. Sp } 1 \\
\text { Bantu klien untuk mengidentifikasi dan menguraikan perasaan sedihnya dan } \\
\text { keputusasaanya } \\
\text { Bantu klien klien mengenal penyebab putus asa } \\
\text { Bantu klien mengetahui penyebab putus asa } \\
\text { Dukung klien mengungkapkan perasaan posititive dan pengalamannya } \\
\text { 5. Latih retruksiasi pikiran melalui pikiran positive }\end{array}$ & $\begin{array}{l}\text { O : pasien mampu menguraikan dan mengidentifikasi } \\
\text { perasaan sedih dan putus asanya } \\
\text { Pasien mampu mengenal penyebab putus asanya } \\
\text { Pasien mampu mengungkapkan perasaan positivenya } \\
\text { Pasien mampu melatih retruiksasi pikiran nya melalui } \\
\text { pikiran positive } \\
\text { A : keputusasaan (+) } \\
\mathbf{P} \text { : latih pasien untuk }\end{array}$ \\
\hline $\begin{array}{l}\text { Tanggal : } 17 \text { Oktober } 2021 \\
\text { Jam : } 14.00-15.20 \text { wib } \\
\text { Dx : Keputusasaan } \\
\text { 1. Memberi salam } \\
\text { 2. Membina hubungan saling percaya } \\
\text { 3. Memahami keadaan pasien } \\
\text { 4. Sp } 1 \\
\text { Bantu klien untuk mengidentifikasi dan menguraikan perasaan sedihnya dan } \\
\text { keputusasaanya } \\
\text { Bantu klien klien mengenal penyebab putus asa } \\
\text { Bantu klien mengetahui penyebab putus asa } \\
\text { Dukung klien mengungkapkan perasaan posititive dan pengalamannya } \\
\text { 5. Latih retruksiasi pikiran melalui pikiran positive. }\end{array}$ & $\begin{array}{l}\text { S : Sedih } \\
\text { O : } \\
\text { Pasien mampu melatih retruiksasi pikiran nya melalui } \\
\text { pikiran positive } \\
\text { A : Keputusasaan (-) } \\
\mathbf{P} \text { : latih pasien untuk } \\
\quad \text { a. Latih retruksiasi pikiran melalui pikiran positive }\end{array}$ \\
\hline
\end{tabular}




\section{BAB 4}

\section{PEMBAHASAN}

Setelah penulis melaksanakan asuhan keperawatan kepada Ny. E dengan Kecemasan di jalan Amal luhur maka penulis pada BAB ini akan membahasan kesenjangan antara teoritis dengan tinjauan kasus. Pembahasan dimulai melalui tahapan proses keperawatan yaitu pengkajian, diagnosa keperawatan, perencanaan, pelaksanaan dan evaluasi.

\subsection{Tahap Pengkajian}

Selama pengkajian dilakukan pengumpulan data dari beberapa sumber, yaitu dari pasien dan tetangga sekitar. Maka penulis melakukan pendekatan kepada pasien melalui komunikasi teraupetik yang lebih terbuka membantu klien untuk memecahkan perasaannya dan juga melakukan observasi kepada pasien. Adapun upaya tersebut yaitu :

a. Melakukan pendekatan dan membina hubungan saling percaya diri pada klien agar klien lebih terbuka dan lebih percaya dengan menggunakan perasaan.

b. Mengadakan pengkajian klien dengan wawancara Dalam pengkajian ini, penulis tidak menemukan kesenjangan karena ditemukan hal sama seperti: diteori: Kecemasan adalah keadaan emosi dan pengalaman subyektif individu, tanpa objek yang spesifik karena ketidaktahuan dan mendahului pengalamanya yang baru seperti penyakitnya saat ini

\subsection{Tahap perencanaan}

Perencanaan dalam proses keperawatan lebih dikenal dengan rencana asuhan keperawatan yang merupakan tahap selanjutnya setelah pangkajian dan penentuan diagnosa keperawatan. Pada tahap perencanaan penulis hanya menyusun rencana tindakan keperawatan sesuai dengan pohon masalah keperawatan yaitu : Kecemasan. Pada tahap ini antara tinjauan teoritis dan tinjaun kasus tidak ada kesenjangan sehingga penulis dapat melaksanakan 


\section{BAB 4}

\section{PEMBAHASAN}

Setelah penulis melaksanakan asuhan keperawatan kepada Ny. E dengan Kecemasan di jalan Amal luhur maka penulis pada BAB ini akan membahasan kesenjangan antara teoritis dengan tinjauan kasus. Pembahasan dimulai melalui tahapan proses keperawatan yaitu pengkajian, diagnosa keperawatan, perencanaan, pelaksanaan dan evaluasi.

\subsection{Tahap Pengkajian}

Selama pengkajian dilakukan pengumpulan data dari beberapa sumber, yaitu dari pasien dan tetangga sekitar. Maka penulis melakukan pendekatan kepada pasien melalui komunikasi teraupetik yang lebih terbuka membantu klien untuk memecahkan perasaannya dan juga melakukan observasi kepada pasien. Adapun upaya tersebut yaitu :

c. Melakukan pendekatan dan membina hubungan saling percaya diri pada klien agar klien lebih terbuka dan lebih percaya dengan menggunakan perasaan.

d. Mengadakan pengkajian klien dengan wawancara Dalam pengkajian ini, penulis tidak menemukan kesenjangan karena ditemukan hal sama seperti: diteori: Kecemasan adalah keadaan emosi dan pengalaman subyektif individu, tanpa objek yang spesifik karena ketidaktahuan dan mendahului pengalamanya yang baru seperti penyakitnya saat ini

\subsection{Tahap perencanaan}

Perencanaan dalam proses keperawatan lebih dikenal dengan rencana asuhan keperawatan yang merupakan tahap selanjutnya setelah pangkajian dan penentuan diagnosa keperawatan. Pada tahap perencanaan penulis hanya menyusun rencana tindakan keperawatan sesuai dengan pohon masalah keperawatan yaitu : Kecemasan. Pada tahap ini antara tinjauan teoritis dan tinjaun kasus tidak ada kesenjangan sehingga penulis dapat 
melaksanakan tindakan seoptimal mungkin dan didukung dengan seringnya bimbingan dengan pembimbing.

Secara teoritis digunakan cara strategi pertemuan sesuai dengan diagnosa keperawatan yang muncul saat pengkajian. Adapun upaya yang dilakukan penulis yaitu :

1. Klien mengungkapkan ketidakpastian tentang fluktuasi tingkat energi dan bersikap pasif.

2. Klien menunjukan sikap apatis, depresi terhadap perburukan fisik yang terjadi dengan mengabaikan kepatuhan pasien terhadap program pengobatan

3. Klien mengalami ketergantungan pada orang lain yang dapat mengakibatkan ititabilitas, ketidaksukaan, marah dan rasa bersalah. Klien tidak melakukan praktik perawatan diri ketika ditantang. Klien tidak ikut memantau kemajuan pengobatan. Klien menunjukan ekspresi ketidakpuasan terhadap ketidakmampuan melakukan aktivitas atau tugas sebelumnya. Klien menunjukan ekspresi keraguan tantang performa peran.

\subsection{Tahap Implementasi}

Pada tahap implementasi, penulis hanya mengatasi 1 masalah keperawatan yakni: diagnosa keperawatan Kecemasan merupakan keadaan emosi dan pengalaman subyektif induvidu,tanpa objek spesifik karena ketidaktahuan dan mendahului semua pengalaman yang di alami penyakit Bells Palsy.

\subsection{Tahap Evaluasi}

Pada tinjauan teoritis evaluasi yang diharapkan adalah :

a. Membina hubungan saling percaya

b. Mengenali dan mengekspresikan emosinya

c. Mampu mengenal ansietas

d. Mampu mengatasi ansietas melalui teknik releksasi

e. Mampu mengatasi ansietas dengan terapi sugesti positif

f. Mampu mengatasi ansietas melalui hipnotis lima jari.

g. Mampu mengatasi ansietas melalui kegiatan spritual keagamaan. 


\section{BAB 5}

\section{PENUTUP}

\subsection{Kesimpulan}

Berdasarkan uraian pada pembahasan diatas, maka penulis dapat disimpulkan bahwa:

1. Pengkajian dilakukan secara langsung pada klien dan juga dengan menjadikan status klien sebagai sumber informasi yang dapat mendukung data-data pengkajian. Selama proses pengkajian, perawat mengunakan komunikasi terapeutik serta membina hubungan saling percaya antara perawat-klien. Pada kasus kecemasan dengan penyakit Bells Palsy

2. Diagnosa keperawatan yang utama pada klien dengan Kecemasan: Bells Palsy

3. Perencanaan dan implementasi keperawatan disesuaikan dengan strategi pertemuan pada pasien.

4. Evaluasi keperawatan yang dilakukan menggunakan metode subyektif, obyektif, assessment dan planing.

\subsection{Saran}

1. Untuk institusi pendidikan

Diharapkan lebih meningkatkan pelayanan pendidikan yang lebih tinggi dan menghasilkan tenaga kesehatan yang profesional berwawasan global

2. Untuk keluarga

Diharapkan agar individu dan keluarga bisa mengerti tentang penyakit Bells Palsy, dan meningkatkan perilaku hidup sehat dengan tujuan meningkatkan kualitas hidup. 


\section{DAFTAR PUSTAKA}

1. Marbun, A., Pardede, J. A., \& Perkasa, S. I. (2019). Efektivitas Terapi Hipnotis Lima Jari terhadap Kecemasan Ibu Pre Partum di Klinik Chelsea Husada Tanjung Beringin Kabupaten Serdang Bedagai. Jurnal Keperawatan Priority, 2(2), 92-99..https://doi.org/10.34012/jukep.v2i2.568

2 Hulu, E. K., \& Pardede, J. A. (2016). Dukungan Keluarga Dengan Tingkat Kecemasan Pasien Pre Operatif Di Rumah Sakit Sari Mutiara Medan. Jurnal Keperawatan, 2(1).

3 Pardede, J. A., Simanjuntak, G. V., \& Waruwu, J. F. A. P. (2020). Penurunan Tingkat Kecemasan Pasien HIV/AIDS melalui Terapi Hipnotis Lima Jari. Coping: Community of Publishing in Nursing, 8, 85-90.

4 Pardede, J. A., \& Simamora, M. (2020). Caring Perawat Berhubungan dengan Kecemasan Orangtua yang Anaknya Hospitalisasi. Jurnal Penelitian Perawat Profesional, 2(2), 171-178. https://doi.org/10.37287/jppp.v2i2.93

5. Pardede, J. A. (2020). Terapi Keluarga.

6. Stuart,G.W. (2009). Principles and Practice of Psychyatric Nursing. 8th edition. Missouri: Mosby.

7. Stuart, G. W., Keliat, B. A., \& Pasaribu, J. (2016). Principal and practice of mental health nursing. Edisi Indonesia. Jakarta: Elsevier

8. Amanati, S., Purnomo, D., \& Abidin, Z. (2017). Pengaruh Infra Red dan Elektrical Stimulation serta Massage terhadap Kasus Bell's Palsy Dekstra. Jurnal Fisioterapi dan Rehabilitasi, 1(1), 9-15. https://doi.org/10.33660/jfrwhs.v1i1.9

9. Nurkholbiah, C., \& Halimah, E. (2016). Terapi untuk Bell's Palsy Berdasarkan Tingkat Keparahan. Farmaka, 14(2), 4149. https://doi.org/10.24198/jf.v14i2.10807

10. Nurhalimah. (2016). Keperawatan Jiwa. Jakarta: Kemenkes.

11. Nurhalimah. (2017). Modul Ajar Konsep Keperawatan Jiwa.Jakarta: AIPViki

12. Budi Anna,dkk.(2019).Asuhan Keperawatan Jiwa.Jakarta;EGC

13. Nourmalita, M. (2016). Pengaruh Citra Tubuh terhadap Gejala Body Dismorphic Disorder yang Dimediasi Harga Diri pada Remaja Putri. 
In Seminar ASEAN 2nd Psychology \& Humanity. Psychology Forum $U M M$ (pp. 546-555).

14. M Mulyana, M. M., Yunus, B. M., \& Zulaeha, E. (2020). Mengatasi putus asa: Konsep problem solving putus asa persepektif tafsir tematik. Digital Library Sunan Gunung Djati Bandung. http://digilib.uinsgd.ac.id/id/eprint/30664

15. Abidin, Z., Amin, A. A., \& Purnomo, D. (2017). Pengaruh Infra Red dan Massage terhadap Bell's Palsy Dextra. Jurnal Fisioterapi dan Rehabilitasi, 1(1), 41-48. https://doi.org/10.33660/jfrwhs.v1i1.9

16. Pardede, J. A., \& Simangunsong, M. M. (2020). Family Support With The Level of Preschool Children Anxiety in the Intravenous Installation. Jurnal Keperawatan Jiwa (JKJ): Persatuan Perawat Nasional Indonesia, 8(3), 223234.https://doi.org/10.26714/jkj.8.3.2020.223-234 
